\title{
The Effect of Earnings Management on the Asymmetric Timeliness of Earnings
}

\author{
Juan Manuel García Lara, Beatriz García Osma and \\ Araceli Mora*
}

\begin{abstract}
Is earnings management affecting (driving) the measures of earnings conservatism? Ball et al. (2000) point out that the asymmetry in the recognition of good and bad news in earnings (faster recognition of bad news: earnings conservatism) is more pronounced in common-law than in code-law based accounting regimes. However, comparative studies on earnings conservatism in Europe have failed to identify significant differences between common-law and code-law based countries. We argue that in code-law based countries managers have incentives to reduce earnings consistently. This enhances the association between earnings and returns in bad news periods. We find that after controlling for discretionary accruals, the differential earnings response to bad news in Germany and France decreases significantly.
\end{abstract}

Keywords: conservatism, earnings management, Europe, comparability

\footnotetext{
* The first and second authors are from Lancaster University. The third author is from Universidad de Valencia, Spain. They gratefully acknowledge the helpful comments and suggestions of an anonymous referee, Steve Young and Ken Peasnell. They acknowledge financial contribution from the Valencian Institute of Economic Research (IVIE), the Spanish Ministry of Science and Technology (SEC2002-04608-C02-01/2) and from the European Commission (HPRN CT 2000-00062). The paper has benefited from presentations at the 2003 AECA meeting; the accounting research workshop at the Amsterdam Graduate Business School; the workshop on empirical research on financial accounting at the University of Alicante, the EIASM workshop on capital market research in accounting at Goethe Universität Frankfurt am Main, the 2004 EAA Conference, the 2004 BAA Conference, a seminar at the University Carlos III Madrid, the 2004 JBFA annual Conference on capital markets and the 2004 AAA annual meeting. Juan Manuel García Lara acknowledges the financial contribution of Lancaster University Management School Pump Priming Research Grants, Lancaster University Small Grants Scheme (AFA7620), and the Nuffield Foundation, through their Small Grant Scheme (SGS/00963/G).
}

Address for correspondence: Juan Manuel García Lara, Lancaster University Management School, Department of Accounting and Finance, Bailrigg, Lancaster LAl 4YX, UK. e-mail: j.garcialara@lancaster.ac.uk 


\section{INTRODUCTION}

The seminal paper by Basu (1997) on income statement (earnings) conservatism is the starting point of a flourishing stream of accounting research on conservatism and other properties of earnings. However, a certain amount of concern has been expressed about how to empirically disentangle earnings conservatism from earnings management or earnings smoothing. The measures of earnings conservatism derived from Basu's model are affected by the extent and pervasiveness of earnings management.

Ball et al. (2000) explain that due to the different economic role of financial statements in common-law and code-law based accounting regimes, earnings conservatism is expected to be more pronounced in common-law based countries. Although they test this hypothesis successfully, comparing the US to code-law based countries, comparative studies on a European context, such as Giner and Rees (2001), García Lara and Mora (2004) or Raonic et al. (2004), fail to find significant differences between common-law and code-law based countries in Europe. Although the demand for conservative measures is embedded in all conceptual frameworks of accounting, the incentives managers have to engage in conservative practices will be directly linked to the litigation threats, which are expected to differ between common-law and code-law based countries.

We argue that these surprising results (similar level of earnings conservatism in the UK and in continental European countries) are attributable to differences in earnings management practices across European countries. In line with this argument, a recent study by Leuz et al. (2003) shows that there are significant differences in earnings management (very broadly defined to encompass several earnings management practices) between countries.

In our study, we analyse in a first step the existence of earnings conservatism, that is, whether bad news is captured faster than good news in financial statements in France, Germany and the UK. Consistent with prior studies, we do not find significant differences in the level of conservatism between the three countries. In a second step, we control for the existence of earnings management, and re-examine earnings conservatism in the three countries under study, as we think that continental European managers have incentives to manage earnings 
downwards consistently. We tind that the difterential recognition speed of bad news decreases significantly in France and Germany when we use a measure of unmanaged earnings (earnings minus discretionary accruals) instead of observed earnings. Once we correct for discretionary accruals, the differences in earnings conservatism between the UK (common-law) and France and Germany (code-law) become significant.

Our paper contributes to the growing body of literature on accounting conservatism. We attempt to shed additional light on the differences in the properties of earnings across European countries. We think that this is an issue of especial interest in this particular moment given that a key objective of the European Commission is to ensure the comparability of accounting numbers of EU firms. Analysing the differences in earnings properties before the implementation of the International Financial Reporting Standards (IFRSs) establishes a benchmark for assessing the effects of EU-wide IFRS implementation.

The remainder of the paper is as follows. In Section 2 we discuss previous evidence on earnings conservatism and describe the effect that earnings management has on the measures of earnings conservatism. In Section 3 we analyse the prior literature on earnings management, focusing on income-decreasing motivations. Section 4 contains the research design. In Section 5 we present our results, and finally, in Section 6 we show the conclusions and offer some directions for further research.

\section{CONSERVATISM AND EARNINGS MANAGEMENT}

Conservatism is described in most regulatory accounting frameworks as a 'prudent reaction to uncertainty' (FASB 1980, SFAC 2). In the IASB framework (IASC, 1989), it is stated that prudence (conservatism) implies that:

[...] assets or income are not overstated and liabilities or expenses are not understated.

However, it also points out that prudence does not allow:

the deliberate understatement of assets or income, or the deliberate overstatement of liabilities or expenses, because the financial statements would not be neutral and, therefore, not have the quality of reliability. 
Cionsequently, the deliberate and consistent understatement of income or overstatement of expenses should not be described as conservatism, or interpreted as desirable properties of accounting numbers, as they would lead to the contravention of qualitative characteristics such as neutrality or representational faithfulness. The practices that through the understatement of income or overstatement of expenses go above and beyond the conservatism principle and undermine the reliability of accounting information should be considered as earnings management practices, as their objectives deviate from the protection of investors and respond to managers' own incentives.

Looking at conservatism from a timing perspective, Basu (1997) interprets conservatism as capturing accountants' tendency to require a higher degree of verification for recognizing good rather than bad news in earnings. Bad news is reflected in the profit and loss account faster than good news. In contrast to traditional definitions of conservatism based on the understatement of shareholders' equity (Feltham and Ohlson, 1995), earnings conservatism is a question of the timing and sequencing of gains and losses with respect to their associated cash flows (Givoly and Hayn, 2000). Using this interpretation of conservatism, Basu (1997) finds evidence consistent with the existence of earnings conservatism in the US, using the rate of return as a proxy for news in the following regression:

$$
E / P_{t-1}=\beta_{0}+\beta_{1} D+\beta_{2} R+\beta_{3} R D
$$

where $E$ is earnings per share; $P$ is share price; $D$ is a dummy variable that equals 1 when the rate of return is negative, 0 otherwise; and $R$ is the rate of return. In this regression, $\beta_{3}$ captures the differential recognition speed of bad news in earnings, with respect to good news (captured by $\beta_{2}$ ). However, $\beta_{3}$ will be influenced not only by the investor-protective conservative practices described in the conceptual frameworks, but also by the unwanted deliberate conservatism that we argue should be classified as earnings management. When managers have incentives to reduce or delay the recognition of earnings, they take additional income-decreasing measures that go beyond the investor protection objectives as defined in the conceptual frameworks, thereby increasing the $\beta_{3}$ coefficient in a Basu 
(19y/) type regression. However, this increase in $\beta_{3}$ responds to earnings management practices, and not to conservatism.

As cash flows capture news symmetrically, accruals will be used to achieve conservatism as defined in the conceptual frame works. If we decompose accruals into their non-discretionary (normal) and discretionary (abnormal) components, conservatism should be reflected in the non-discretionary component, while undesirable conservatism, that is, unnecessary overstatement of expenses or understatement of gains, would be reflected in discretionary accruals, leading to a loss in reliability of accounting information. ${ }^{1}$ Therefore, discretionary accruals will contribute to increase $\beta_{3}$ in the Basu model, inflating Basu's conservatism measure. That is, discretionary accruals will be used to 'abuse' the conservatism principle.

Nevertheless, Guay et al. (1996) argue, in a US context, that managers use discretionary accruals to produce a more reliable measure of firm performance, that is, they make earnings timelier. However, it could be argued that the threat of litigation will result in managers having incentives to use their discretion over accruals to align earnings and returns only in bad news periods. Consequently, discretionary accruals would capture news asymmetrically, and will contribute to increase Basu's $\beta_{3}$ coefficient. In other institutional contexts (continental Europe) where managers have incentives to decrease earnings for tax, dividend or other purposes, discretionary accruals will also be contributing to align earnings and returns in bad news periods, but not in good news periods. That is, if given a predefined set of accrual choices, managers choose those that will lead to more reduced earnings numbers, we will observe a more pronounced association between earnings and returns in bad news periods. Again in this case, discretionary accruals will capture news asymmetrically.

Previous research on earnings conservatism in an international context shows that common-law accounting regimes

1 Managers could also be using real operating instruments to manipulate earnings, affecting cash flows in such a way that they would not capture news symmetrically. However, real operating decisions to manage earnings can reduce shareholder value and are considered more costly and visible than pure financial decisions. Therefore, managers are expected to prefer accounting manipulation to real manipulation that affects cash flows (Peasnell et al., 2000b). 
(the $\cup K$ being the clearest example in Europe) are more earnings conservative than code-law based accounting regimes (all European continental countries, except The Netherlands). According to Ball et al. (2000), this difference is explained by the different economic role of financial statements in the two types of countries. In common-law countries, the ownership of the company is spread over a wide number of shareholders, who are willing and able to sue managers or auditors if they do not disclose bad news in a timely way through financial statements. As a response to this external demand for conservative measures, managers increase the asymmetry in the recognition of good and bad news in earnings. Thus, litigation risk is the main trigger of earnings conservatism in common-law based countries. In contrast, in code-law based countries, the main providers of capital funds are financial institutions, fundamentally banks. In these countries, demand for timely information in the annual accounts is less important, since these financial institutions already know about the financial affairs of the company through other timelier sources.

The fact that banks are the main providers of finance in codelaw based countries leads to greater balance sheet conservatism. Banks demand reduced values of shareholders' equity to assess the borrowing capacity of the firm from a prudent perspective. Their objective is to be sure that if the firm faces some kind of financial distress, they will be able to recover the investment through the liquidation of assets. Consequently, greater balance sheet conservatism is observed in code-law based countries (Joos and Lang, 1994; Joos, 1997; and García Lara and Mora, 2004). The existence of balance sheet conservatism also reduces the possibility of engaging in earnings conservatism practices in code-law based countries. Pope and Walker (2003) show that earnings conservatism decreases with balance sheet conservatism. If a particular asset is not recognised in the balance sheet, news about that particular asset will not be captured in earnings, and will not lead to any asymmetry in news recognition in earnings. Balance sheet conservatism should consequently be contributing to smaller earnings conservatism in code-law based countries, consistent with Ball et al.'s (2000) hypothesis.

However, the studies that analyse earnings conservatism focusing on European countries, e.g. Giner and Rees (2001), 
Garcia Lara and Mora (2UU4) and Kaonic et al. (2UU4), tind that the differences between the $\mathrm{UK}$ and continental European countries are not as pronounced as one might expect. ${ }^{2}$ Their results suggest that the differences (if any) are not significant. No satisfactory explanations for these conflicting results have appeared in the literature. The reduced litigation risk faced by managers and auditors and the greater balance sheet conservatism in code-law based countries should lead to differences in earnings conservatism between the UK and continental European countries. We test the hypothesis that earnings management practices differ substantially between countries and affect directly the measure of earnings conservatism, increasing $\beta_{3}$ in continental European countries. In our empirical study, we find that discretionary accruals in Continental European countries show a larger contemporary association with returns in bad news periods, biasing upwards the Basu (1997) $\beta_{3}$ coefficient, which in the absence of discretionary accruals would give an unbiased measure of conservatism.

\section{EARNINGS MANAGEMENT AS A DRIVER FOR EARNINGS CONSERVATISM}

Jensen and Meckling (1976) point out that the lack of alignment between managers and shareholders' interests creates incentives for managers to use the firm's resources in a selfbeneficial way. In line with this general idea, earnings management can be defined as a purposeful alteration of the financial reports to either 'mislead some stakeholders about the underlying performance of the company or to influence contractual outcomes' (Healy and Wahlen, 1999, p. 368). This broad definition encompasses a number of practices carried out by managers, generally leading to a reduced variability of reported income (earnings smoothing) or to covering deteriorating firm performance. Recent studies examine how widespread and pervasive these practices are, seeming to affect most publicly traded companies and being common to firms

2 In the case of Raonic et al. (2004) they use only cross-listed firms, leading to a greater homogeneity between firms in their sample. Consequently, their results showing no differences between countries are not surprising. 
all over the world (see Healy and Wahlen, 1yyy; or Nechow and Skinner, 2000; for reviews of the earnings management literature). However, the objective and direction of these earnings management practices vary depending on the incentives that managers face.

Different institutional environments lead to differences in managers' incentives to manipulate earnings. In code-law based countries accounting income is strongly linked to current payouts to employees, managers, shareholders and the government. If this link contributes to managerial incentives to manage earnings downwards, it enhances the association between earnings and returns in bad news periods. Also, the association between earnings and returns in good news periods decreases (one could think that the incentives to manage earnings downwards are more pronounced in good news periods), with which the apparent bad news effect is therefore greater. If this hypothesis holds, when analysing earnings conservatism using a Basu (1997) type regression, the differential bad news coefficient with respect to good news is artificially inflated. We provide the following arguments to explain why continental European managers engage in persistent income decreasing strategies: (i) the link between dividends and earnings, (ii) the pecking order theory, (iii) the link between earnings and taxation, (iv) the reduced incentives to manage earnings upwards, and (v) the existence of strong labour unions.

\section{(i) The Link Between Dividends and Earnings}

The relationship between accounting numbers and payments to shareholders is much stronger in countries where investor protection is weak. La Porta et al. (2000) argue that firms in countries where investor protection is low (and they give the example of French type civil (code) law countries) try to establish a good reputation for 'moderation in expropriating shareholders' to be able to raise funds in capital markets. According to La Porta et al. (2000), a reputation for good treatment of shareholders is crucial in countries with weak investor protection, that is, where shareholders are not able to sue managers successfully. Firms in these countries use dividends as a substitute for legal protection, and they are keen to show 
shareholders high dividend payout ratıos. However, these high payout ratios can be achieved also by managing earnings downwards. La Porta et al. (2000) explicitly argue that in code-law based countries reported earnings could be lower than what they call 'true earnings' (p. 11). This is why they calculate payout ratios not only as Dividends/Earnings, which can be manipulated, but also as Dividends/Sales.

In a similar way, Harris et al. (1994) argue that commercial regulation in Germany is strengthening the link between earnings and dividends, giving German managers the incentive to manage earnings downwards so that they can more easily shape their dividend policies. The German Stock Corporation Law only allows managers to retain half of the net income of the year. The rest, including certain retained earnings, are left to the discretion of shareholders at the annual meeting. According to Harris et al. (1994), this establishes a strong link between earnings and dividends, creating incentives to manage reported earnings to attain a desired dividend policy, because higher reported earnings create shareholder pressure for higher dividends. In their study they find that earnings payout ratios are greater in Germany than in the US and link this result to incentives for lower reported earnings. There is also evidence of dividend-driven earnings management in a code-law based country (Finland) in the study by Kasanen et al. (1996), where the authors argue that the firm's motivations to pay dividends in codelaw based countries (apart from Finland, their country under study, they put the examples of France, Germany and Sweden) are demand driven because of the dominant role of institutional ownership. ${ }^{3}$

\section{(ii) The Pecking Order Theory}

The pecking order theory (Myers, 1984; and Myers and Majluf, 1984) offers a theoretical framework where managers have

3 In the extreme case of countries with illiquid markets and high transaction costs (e.g. Finland, which is the case of Kasanen et al., 1996) one could expect income-increasing dividends driven earnings management, to achieve a predetermined level of dividends. This, however, does not apply to France and Germany, as financial markets in these countries are liquid and transactions costs are more reduced. 
incentives to decrease earnings. I he pecking order theory argues that managers prefer internal funds to finance their investment strategies. This, according to Fama and French (2002), has important implications for the dividend policy of the company. If the pecking order theory holds, then managers will retain as much earnings as they can, which in the German case cannot be more than $50 \%$, as established by the Stock Corporation Law. Ehrhardt and Schmidt (2003) test whether German managers behave according to the pecking order theory and argue (p. 3) that:

part of net earnings disposable for dividend payments and retention, respectively, is reduced through accruals management. While the retainable amount of (explicit) net earnings is limited by German payout rules, the amount of net earnings reduced through accruals management is 'retained' completely. That is, the internal funds disposable via open retention policy might be extended through hidden action via discretionary variations of accruals.

Their empirical results show that German managers behave in accordance with the pecking order theory and that they avoid earnings increases through earnings management given that it is the only way to fully retain income increases in order to enhance internal funds (p. 21).

\section{(iii) The Link Between Earnings and Taxation}

In code-law based countries taxes are closely tied to reported earnings. For individual accounts (also for consolidated accounts in Germany) there are no differences between taxable income and profit before tax. That is, the flow-through method is used. Looking at the German case, Seckler (1998, p. 361) points out:

commercial accounts in Germany are linked directly with tax accounts. [...] the accounting treatment in the commercial financial statements in general directly affects the tax position of the company.

This link between accounting and taxation gives German managers the incentive to manage earnings downwards to delay (or even avoid) tax payments. The situation in France, regarding the linkage between accounting and taxation is 
simılar." Lamb et al. (19y8) analyse the linkage between accounting and taxation in the US, the UK, France and Germany, and they reach the conclusion that the linkage is much more pronounced in France and Germany than in the US and the UK, although differences also exist between France and Germany. Harris et al. (1994) stress the link between taxation and accounting, pointing out that one of the main objectives of financial statements in Germany is to compute taxable income. Finally, Kasanen et al. (1996) argue that when taxes are closely tied to reported earnings there is a strong incentive to report low earnings in general. Although they analyse the Finnish stock market, they state that the situation is similar in, at least, France, Germany and the Scandinavian countries.

\section{(iv) Reduced Incentives to Manage Earnings Upwards}

Aside from the previously discussed incentives for income decreasing earnings management, the more concentrated ownership and the lesser importance of capital markets as financing mechanisms in continental European countries is expected to reduce the incentives to engage in income increasing strategies. As earnings are not such an important signalling device, incentives for example, to meet or beat analysts' forecasts will not be

4 In our empirical study we use data from DataStream, which means that we work with consolidated financial statements. In France, a new law was approved in 1998 allowing (though not obliging) French listed firms to prepare their consolidated accounts following US-GAAP or IASB standards, even if they use the French GAAP to prepare their individual accounts. This means that from 1999, our argument of the link between accounting and taxation to explain managers' incentives to manage earnings downwards would not hold for those firms using US or international standards. However, this only affects a very reduced number of observations and only from 1999 onwards (our sample covers 1990-2001). In any case, and as Richard (2001, p. 1135) points out, 'this change cannot be done at once and [...] is only an expectation of change'. The situation is also similar in Germany, where a new law was approved in 1998 similar to the one already explained for the French case, allowing German firms to prepare group accounts according to internationally accepted accounting principles (i.e. FASB or IASB) instead of the German group accounting law. Again, the impact in our sample is reduced given that it could only be affecting a reduced number of observations from 1999 onwards. In any case, and to avoid the impact that these observations could have on the results, we replicate the analysis restricting our sample to the time period 1990-1998. We find that our results are not sensitive to this change in the sample. 
as important as in countries where ownership is widespread and capital market pressures are more pronounced. ${ }^{5}$

\section{(v) The Existence of Strong Labour Unions}

Another important institutional feature in continental countries that could be leading firms to manage earnings downwards is the existence of strong labour unions, which have substantial representation in the boards of directors. Although there is no empirical evidence, Harris et al. (1994) support the hypothesis that German firms are hesitant to report high earnings for fear of strengthening the position of labour unions in their negotiations with the firm. This argument, however, should be taken cautiously, as there is somewhat mixed evidence of income decreasing earnings management driven by the presence of strong labour unions (Liberty and Zimmerman, 1986; and DeAngelo and DeAngelo, 1991).

Supporting our arguments of differences in earnings management across countries, a recent study conducted by Leuz et al. (2003) builds an aggregate earnings management measure, and compares it across a comprehensive sample of countries, including the UK, France and Germany. They find that earnings management practices differ significantly across countries, and that the divergences are linked to the different institutional environments in each country. Their evidence suggests that countries with less dispersed ownership structure and weak investor rights (e.g. Germany) engage more in earnings management, even if there is strong legal enforcement. They argue explicitly that:

earnings management is more pervasive in countries where the legal protection of outside investors is weak, because in these countries insiders enjoy greater private control benefits and hence have stronger incentives to obfuscate firm performance (Leuz et al., 2003, p. 507).

5 There could be incentives to engage in income increasing strategies, especially in the UK, around corporate events such as mergers, IPOs or SEOs (Friedlan, 1994; Teoh et al., 1998; and Rangan, 1998). However, these strategies are probably transitory, and the analysis of the effect that they could have on earnings conservatism is beyond the scope of this study. One could think however, that these strategies would increase the coefficient on good news around the corporate event, and the coefficient on bad news in subsequent years. 
Cionsequently, litıgation risk plays an important role in mitıgating earnings management practices. In those countries where shareholders do not have the opportunity to sue managers (continental Europe), managers will have more room to manage earnings. Consistent with this idea, they find that French and German managers are more likely to engage in earnings management practices than their counterparts in the US and the UK.

Their results are consistent with our hypothesis about the unequal effect that earnings management can have on the measure of earnings conservatism in the sense that they find German and French managers more likely to engage in earnings management practices than those in the UK. In their study, Leuz et al. (2003) work with a very broad definition of earnings management, including measures of earnings smoothing using accruals and measures of discretion in reported earnings, focusing not only on accruals but also on small loss avoidance. In our paper, we identify earnings management by measuring discretionary accruals. To calculate discretionary accruals we use the models proposed by Jones (1991), Dechow et al. (1995) and Peasnell et al. (2000a).

In our empirical study we show that earnings management is a key factor enhancing the measures of earnings conservatism in European continental countries. However, and in spite of the fact that it increases the asymmetry, we should not refer to this phenomenon as earnings conservatism, since it is only attributable to earnings management techniques implemented by managers to accomplish certain objectives regarding tax payments, the dividend policy of the firm and/or the relation with other third parties like labour unions. These objectives are different from complying with the prudence or conservatism principle as stated in the conceptual frameworks (FASB, IASB or ASB), and enhanced (enforced) by a greater development of financial markets and a more litigious environment.

\section{RESEARCH DESIGN}

Our empirical tests compare the results of analysing the existence of earnings conservatism in European countries (UK, 
France and (iermany), betore and atter taking into account the effect of earnings management.

For our tests, we use the model proposed by Basu:

$$
X_{t}=\beta_{0}+\beta_{1} D_{t}+\beta_{2} R_{t}+\beta_{3} R_{t} D_{t}+u_{t}
$$

where $X_{t}$ is earnings before extraordinary items per share (DataStream item 254) deflated by share price at the beginning of the period. $R_{t}$ is the rate of return of the firm, calculated as $\left(P_{t}-P_{t-1}\right) / P_{t-1} \cdot{ }^{6}$ Share prices have been adjusted for stock splits, new equity issues, etc., $D_{t}$ is a dummy variable that takes the value 1 in the case of bad news (negative or zero rate of return) and 0 in the case of good news (positive rate of return). This definition of earnings $\left(X_{t}\right)$ is the one used in previous studies and we use it for our first set of tests. Next, and to disentangle the effect of earnings management from earnings conservatism we build a measure of 'unmanaged earnings'. In this specification with unmanaged earnings, $X^{*}{ }_{t}$ equals earnings before extraordinary items per share minus discretionary accruals per share, deflated by share price at the beginning of the period. In mathematical notation:

$$
X^{*}{ }_{t}=\left(\operatorname{EPS}_{t}-\operatorname{DACCPS}_{t}^{*}\right) / P_{t-1}
$$

where DACCPS* is discretionary accruals per share multiplied by lagged total assets.

We define discretionary accruals (DACC) as the prediction error of the Jones (1991) accruals model. We calculate discretionary accruals using a two-stage approach. Firstly, we use the standard Jones (1991) model as applied cross-sectionally to total accruals (TACC). We measure total accruals (TACC) as the change in non-cash working capital plus depreciation and amortisation. ${ }^{7}$ We then regress total accruals on the change in

6 In our initial tests we do not include dividends so that our results are consistent with prior European research (Pope and Walker, 1999; Giner and Rees, 2001; García Lara and Mora, 2004; and Raonic et al., 2004). We replicate all the analyses including dividends to calculate the rate or return, but our results are not sensitive to this change. 7 Thus, TACC $=\Delta(\mathrm{CA}-\mathrm{CASH})-\Delta(\mathrm{CL}-\mathrm{CBORR})-(\mathrm{DEP}+\mathrm{INT})$, where CA is total current assets (DataStream item 376), CASH is total cash and equivalents (DS375), CL is total current liabilities (DS389), CBORR is borrowings repayable within 1 year (DS309), DEP is depreciation (DS402) and INT is amounts written off intangibles (DS562). 
sales and property, plant and equipment for each Vatastream level-3 industry-year, using all available data, but imposing the restriction of at least six observations per industry-year combination. The model is as follows:

$$
\begin{aligned}
\mathrm{TACC}_{t} / \mathrm{TA}_{t-1}=\beta_{0}\left(1 / \mathrm{TA}_{t-1}\right) & +\beta_{1}\left(\Delta \mathrm{REV}_{t} / \mathrm{TA}_{t-1}\right) \\
& +\beta_{2}\left(\mathrm{PPE}_{t} / \mathrm{TA}_{t-1}\right)+\varepsilon_{t}
\end{aligned}
$$

where TA is total assets (DataStream item 392), $\triangle \mathrm{REV}$ is change in total sales (DataStream item 104) and PPE is gross property plant and equipment (DataStream item 330). The $\triangle \mathrm{REV}$ and PPE terms control for the non-discretionary component of total accruals associated with changes in operating activity and level of depreciation. In the second stage, we use these industryyear ordinary least square parameter estimates from equation (4) to partition the TACC into discretionary accruals (DACC) and non-discretionary accruals (NDACC). NDACC are the predicted part of TACC, while DACC are the residual resulting from this regression. Therefore:

$$
\begin{aligned}
\mathrm{DACC}_{t}=\mathrm{TACC}_{t} / \mathrm{TA}_{t-1}-\mathrm{NDACC}_{t} & \\
=\mathrm{TACC}_{t} / \mathrm{TA}_{t-1}-\left[\hat{\beta}_{0}\left(1 / \mathrm{TA}_{t-1}\right)\right. & +\hat{\beta}_{1}\left(\Delta \mathrm{REV}_{t} / \mathrm{TA}_{t-1}\right) \\
& \left.+\hat{\beta}_{2}\left(\mathrm{PPE}_{t} / \mathrm{TA}_{t-1}\right)\right]
\end{aligned}
$$

where $\hat{\beta}_{0}, \hat{\beta}_{1}$ and $\hat{\beta}_{2}$ are the industry-year parameters estimated in regression (4). ${ }^{8}$

We perform several robustness checks using alternative earnings management proxies and model specifications. First, we estimate DACC using the modified Jones model (Dechow et al., 1995), calculating $\hat{\beta}_{0}, \hat{\beta}_{1}$ and $\hat{\beta}_{2}$ as in equation (4), but subtracting the change in debtors $(\triangle \mathrm{REC})^{9}$ from $\triangle \mathrm{REV}$ at the second stage. Second, we use discretionary working capital accruals as our earnings management proxy, as previous research has argued that long-term accruals such as depreciation are unlikely to be manipulated, and the manipulation

8 We run equation (4) both scaling the intercept and without scaling it. Our results are not sensitive to these alternative specifications, which is in line with the findings of very little differences in the distribution of DACC calculated with or without scaling the intercept reported by Gill de Albornoz and Illueca (2004).

9 Change in debtors is calculated $\triangle \mathrm{REC}=\Delta(\mathrm{DEB}-\mathrm{CDEB})$, where DEB is trade debtors (DataStream item 287), and CDEB is trade debtors due in more than 1 year (DS288). 
ot working capital accruals (WLiA) is less visible (Beneish, 19y8; and Young, 1999). WCA are defined as the change in non-cash working capital, ${ }^{10}$ and they are regressed on the change in sales for each Datastream level-3 industry-year. As with TACC, we calculate DACC using both the standard Jones (1991) and the modified Jones (Dechow et al., 1995) models, therefore obtaining two additional measures of DACC. Third, we calculate DACC using the cross-sectional 'margin model' designed by Peasnell et al. (2000a) as applied to WCA. We regress WCA on $\mathrm{CR}$ and REV, where CR is total sales minus the change in total debtors (DataStream items 104-\$370). ${ }^{11}$ DACC are calculated as the residual resulting from this regression following the same procedure as before.

We include in our sample all observations available in the DataStream 'Live' and 'Dead' files for the UK, France and Germany. We exclude financial firms and firms with accounting periods of more than 380 or less than 350 days. We exclude firms with missing industry information and industryyear combinations with fewer than 6 observations at each of the DataStream level-3 industrial classification groups. Previous to the elimination of extreme values, we estimate discretionary accruals. For the conservatism models we exclude the two extreme percentiles of each variable (observed earnings, unmanaged earnings, rate of return, price and lagged price) per country. The final sample that we use to estimate earnings conservatism consists of 10,131 firm-year observations for the UK, 1,367 for France and 3,245 for Germany, for the period 1990-2001. This sample size, and descriptive statistics in Table 1 correspond to the conservatism model estimated using discretionary accruals obtained from the total accruals version of the Jones (1991) model. The sample size varies slightly with the accruals model used.

10 WCA $=\Delta$ (Total Current Assets - Cash and Cash equivalents $)-\Delta$ (Current liabilities - Borrowings repayable in one year) [DataStream items $\Delta(376-375)-\Delta(389-309)]$.

11 Refer to Peasnell et al. (2000a) for a more detailed explanation of the 'margin model'. 
Table 1

Descriptive Statistics

\begin{tabular}{|c|c|c|c|c|c|c|c|}
\hline Country & N. Obs & Variable & Mean & Median & Std. Dev & Min. & Max. \\
\hline \multirow[t]{5}{*}{ UK } & \multirow[t]{5}{*}{10,131} & $\mathbf{X}$ & 0.038 & 0.066 & 0.139 & -0.968 & 0.365 \\
\hline & & $\mathbf{X}^{*}$ & 0.041 & 0.050 & 0.200 & -1.271 & 1.173 \\
\hline & & return & 0.055 & 0.000 & 0.448 & -0.815 & 2.386 \\
\hline & & dacc & 0.001 & 0.003 & 0.129 & -2.561 & 2.309 \\
\hline & & ndace & -0.041 & -0.043 & 0.686 & -53.480 & 42.225 \\
\hline \multirow[t]{5}{*}{ France } & \multirow[t]{5}{*}{1,367} & $\mathbf{X}$ & 0.041 & 0.053 & 0.095 & -0.954 & 0.363 \\
\hline & & $\mathbf{X}^{*}$ & 0.036 & 0.039 & 0.177 & -1.228 & 1.143 \\
\hline & & return & 0.076 & 0.025 & 0.426 & -0.803 & 2.379 \\
\hline & & dacc & 0.005 & 0.005 & 0.076 & -0.526 & 0.662 \\
\hline & & ndacc & -0.051 & -0.051 & 0.046 & -0.576 & 0.241 \\
\hline \multirow[t]{5}{*}{ Germany } & \multirow[t]{5}{*}{3,245} & $\mathbf{X}$ & 0.017 & 0.035 & 0.121 & -0.934 & 0.354 \\
\hline & & $\mathbf{X}^{*}$ & 0.022 & 0.030 & 0.289 & -1.286 & 1.190 \\
\hline & & return & 0.021 & -0.013 & 0.348 & -0.814 & 2.362 \\
\hline & & dacc & -0.002 & -0.002 & 0.211 & -1.649 & 5.429 \\
\hline & & ndace & -0.050 & -0.056 & 0.169 & -1.411 & 2.791 \\
\hline
\end{tabular}

Notes:

$\mathbf{X}$ is earnings before extraordinary items per share (DataStream item 254), deflated by beginning of period share price.

$\mathrm{X}^{*} \quad$ is earnings before extraordinary items per share (DataStream item 254) minus discretionary accruals per share; deflated by beginning of period share price. Discretionary accruals is defined as dacc times total assets in $t-1$.

return is the rate of return of the firm.

dacc is discretionary accruals, calculated as the residual of the standard Jones (1991) accruals model, as applied to total accruals.

ndacc is non discretionary accruals, estimated as the predicted part of the working capital accruals.

Table 1 contains sample descriptive statistics. ${ }^{12}$ Consistent with the prior literature on earnings management, discretionary accruals are on average close to zero. Both the mean and

12 From Table 1 we can see that there is at least one extreme value in the UK. We replicate our analyses excluding also the 2 (5) top and bottom percentiles, and extreme values of additional variables not included directly in the Basu (1997) regression, such as discretionary and non-discretionary accruals. Results are not sensitive to the exclusion of these observations, but we only remove extreme observations for discretionary and nondiscretionary accruals when we trim outliers directly from these variables. From this sensitivity test we think it is interesting to point out that there is a number of firms with extreme observations of accruals and discretionary accruals. When we eliminate the top and bottom percentile (of discretionary and non-discretionary accruals) we observe that the median discretionary accruals per share multiplied by lagged total assets reduces earnings in France by $17 \%$, in Germany by $7 \%$, and increases earnings in the UK by $4 \%$. 
median for the three countries under study are close to zero. Consistent with the existence of earnings conservatism, earnings ('managed' or 'unmanaged') are negatively skewed. ${ }^{13}$ If we focus on returns, exactly the opposite occurs. The standard deviation of earnings (again, 'managed' or 'unmanaged') is smaller than the standard deviation of returns, consistent with Ball et al.'s (2000) argument that net income is a function of past and present returns.

Figure 1 provides graphical evidence of our empirical expectation that the distribution of observed (managed) earnings differs severely across the three countries. As predicted, the distribution of earnings scaled by beginning of period total assets for Germany and France, shown in Figure 1, Panels B and $\mathrm{C}$ reveals a distinct accumulation of observations just above the zero earnings reference point (i.e. there is an unusually high number of firms reporting 'small profits'). The impression conveyed by Figure 1 is that the discontinuity in the earnings distribution around small earnings is much stronger for Germany and France than for the UK, as is the occurrence of observations in the region that includes the six intervals immediately above zero, showing an accumulation in the area of small profits that would be consistent with a certain aversion to big profits, as firms reporting big profits seem fairly common in the UK but very rare both in France and Germany. ${ }^{14}$ This graphical evidence is consistent with our expectation that the strong link between accounting income to current payouts to employees, managers, shareholders and the government in code-law based countries creates additional managerial incentives to manage earnings downwards. Consistent with this idea, the distribution of earnings is less normal in France and Germany, being more concentrated in the six intervals just to the right of zero. Figure 2

13 From Table 1 we see that in all 3 countries the median is greater than the mean for managed and unmanaged earnings. Additionally, we have also calculated a skewness coefficient for every country, being negative both for managed and unmanaged earnings in all three countries.

14 To a certain degree this evidence could also be consistent with a small loss avoidance explanation, that is, with firms using income-increasing measures to move from small losses to small profits. However, small loss avoidance does not explain why big profits are so rare in France and Germany, and recent research by Dechow et al. (2003) and Beaver et al. (2003) questions the extent to which income-increasing accrual management causes this discontinuity in the distribution of earnings just at zero earnings. 
Figure 1

Histogram of Observed Earnings Levels

Panel A: UK Earnings (scaled by beginning of year total assets) $N=10,131$ Class width 0.01

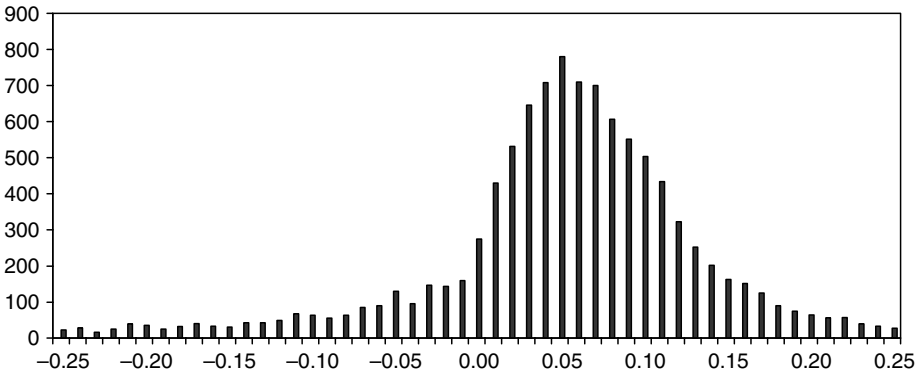

Panel B: Germany Earnings (scaled by beginning of year total assets) $N=3,245$ Class width 0.01

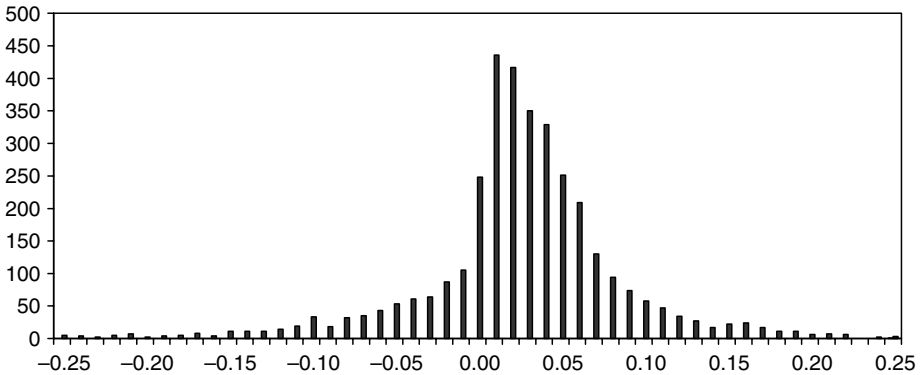

Panel C: France Earnings (scaled by beginning of year total assets) $N=1,367$ Class width 0.01

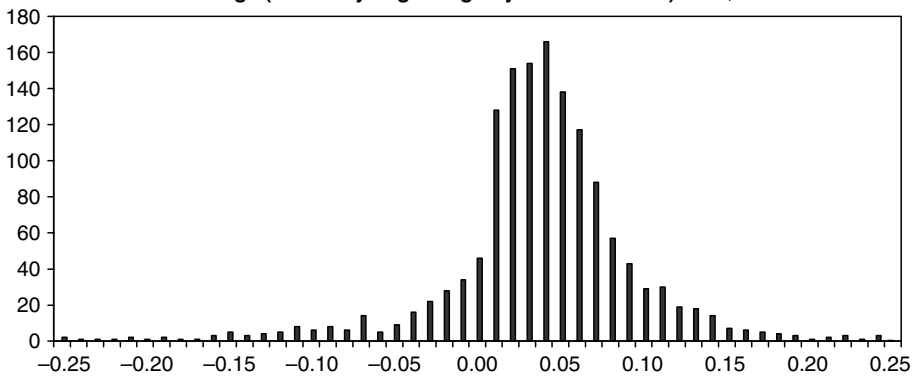


Figure 2

Histogram of Unmanaged Earnings Levels

Panel A: UK Unmanaged Earnings [(DS625/lagDS392) - dacc] $N=10,131$ Class width 0.01

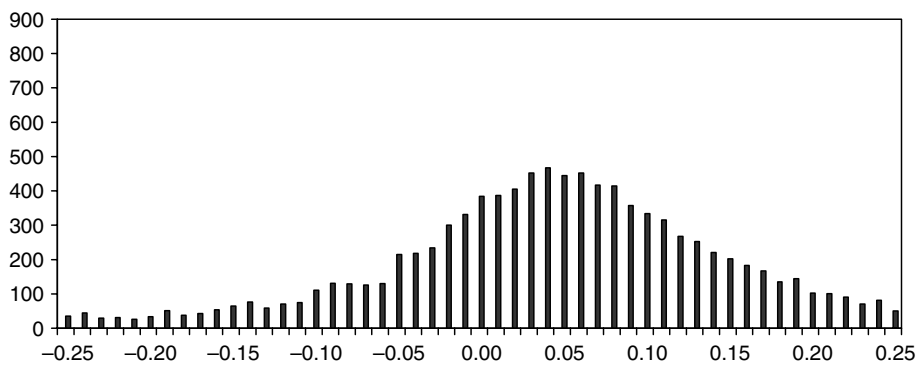

Panel B: Germany Unmanaged Earnings [(DS625/lagDS392) - dacc] $N=3,245$ Class width 0.010

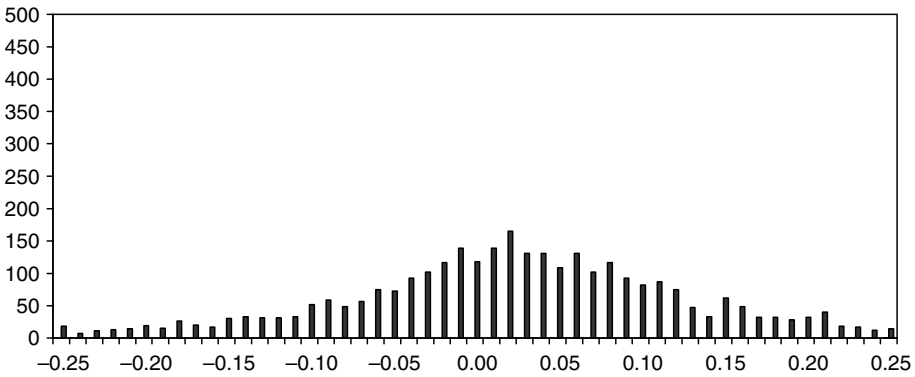

Panel C: France Unmanaged Earnings [(DS625/lagDS392) - dacc] $N=1,367$ Class width 0.01

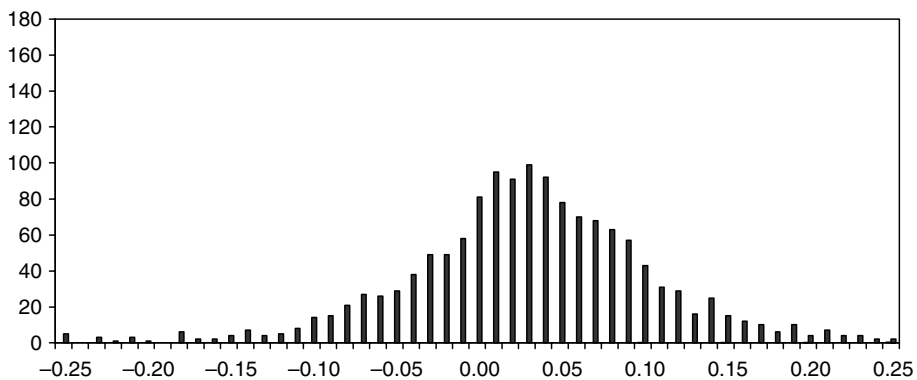


represents the distribution of unmanaged earnings. It can be clearly observed that the histograms are more similar across the three countries, being in all three cases closer to a normal distribution. ${ }^{15}$ This graphical evidence is consistent with differences in discretionary accruals across countries.

\section{RESULTS}

We first analyse the existence of earnings conservatism in each country using the model proposed by Basu (1997). In Basu's model, $\beta_{3}$ shows the differential effect of bad news in earnings relative to good news. In Table 2 , Panel $A$, we see that for all countries $\beta_{3}$ is significantly positive. That is, earnings conservatism exists in all countries. Specifically, $\beta_{3}$ is 0.24 in the UK, 0.22 in Germany, and 0.16 in France. This is consistent with prior literature. Also, the intercept is significantly positive, showing the incorporation of prior period good news into contemporary earnings. The effect of good news in this period $\left(\beta_{2}\right)$ is, as expected, very small in all cases. The adjusted $R^{2}$ s are consistent also with those in previous studies, and around 0.12 . These low values of the $R^{2}$ s are attributable to the asynchrony between accounting information and share prices (the prices leading earnings hypothesis; see for example Easton et al., 1992).

Secondly, we re-run the Basu (1997) model, but recalculating the dependent variable to disentangle the effect of earnings management. We work with a measure of 'unmanaged' earnings that we define as observed earnings per share minus discretionary accruals times lagged total assets per share, discretionary accruals having been previously calculated as the estimation error of the total accruals variant of the standard Jones (1991) accruals model.

In this case, as shown in Panel B in Table 2, the bad news differential coefficient $\left(\beta_{3}\right)$ for the $\mathrm{UK}$ remains approximately the same. It is 0.21 , when it was 0.24 when using observed (managed) earnings. However, in the case of France and Germany, where we expected it to be much smaller, it is now down to 0.05 and 0.08 respectively. That is, there is a reduction

15 This evidence is consistent with the graphical evidence reported by Gore et al. (2002) for the UK. 
Table 2

Earnings Conservatism by Country (Individual Regressions)

\begin{tabular}{|c|c|c|c|c|c|c|c|c|c|c|}
\hline & \multicolumn{5}{|c|}{ Pooled Regressions } & \multicolumn{5}{|c|}{ Fama and MacBeth (1973) Regressions } \\
\hline & $\underset{t-s t a t}{\beta_{0}}$ & $\begin{array}{c}\beta_{1} \\
t \text {-stat }\end{array}$ & $\begin{array}{c}\beta_{2} \\
t \text {-stat }\end{array}$ & $\begin{array}{c}\beta_{3} \\
t \text {-stat }\end{array}$ & Adj. $R^{2}$ & $\begin{array}{c}\beta_{O} \\
t-s t a t\end{array}$ & $\begin{array}{c}\beta_{1} \\
t \text {-stat }\end{array}$ & $\begin{array}{c}\beta_{2} \\
t \text {-stat }\end{array}$ & $\begin{array}{c}\beta_{3} \\
t \text {-stat }\end{array}$ & Adj. $R^{2}$ \\
\hline \multicolumn{11}{|c|}{ Panel A: Observed Earnings } \\
\hline $\mathrm{UK}$ & $\begin{array}{r}\mathbf{0 . 0 7} \\
30.26\end{array}$ & $\begin{array}{l}\mathbf{0 . 0 1} \\
1.37\end{array}$ & $\begin{array}{l}\mathbf{0 . 0 2} \\
3.65\end{array}$ & $\begin{array}{r}\mathbf{0 . 2 4} \\
18.79\end{array}$ & 0.14 & $\begin{array}{r}\mathbf{0 . 0 7} \\
15.37\end{array}$ & $\begin{array}{l}\mathbf{0 . 0 1} \\
1.12\end{array}$ & $\begin{array}{l}\mathbf{0 . 0 3} \\
3.49\end{array}$ & $\begin{array}{l}\mathbf{0 . 2 4} \\
8.02\end{array}$ & 0.17 \\
\hline France & $\begin{array}{r}\mathbf{0 . 0 6} \\
15.82\end{array}$ & $\begin{array}{r}\mathbf{0 . 0 0} \\
-0.34\end{array}$ & $\begin{array}{l}\mathbf{0 . 0 2} \\
2.23\end{array}$ & $\begin{array}{l}\mathbf{0 . 1 6} \\
6.52\end{array}$ & 0.12 & $\begin{array}{l}\mathbf{0 . 0 5} \\
7.37\end{array}$ & $\begin{array}{l}\mathbf{0 . 0 1} \\
0.81\end{array}$ & $\begin{array}{l}\mathbf{0 . 0 4} \\
3.14\end{array}$ & $\begin{array}{l}\mathbf{0 . 2 2} \\
4.73\end{array}$ & 0.15 \\
\hline Germany & $\begin{array}{l}\mathbf{0 . 0 4} \\
9.98\end{array}$ & $\begin{array}{l}\mathbf{0 . 0 1} \\
1.82\end{array}$ & $\begin{array}{l}\mathbf{0 . 0 2} \\
1.50\end{array}$ & $\begin{array}{l}\mathbf{0 . 2 2} \\
9.21\end{array}$ & 0.09 & $\begin{array}{l}\mathbf{0 . 0 4} \\
6.20\end{array}$ & $\begin{array}{l}\mathbf{0 . 0 0} \\
0.74\end{array}$ & $\begin{array}{l}\mathbf{0 . 0 4} \\
1.95\end{array}$ & $\begin{array}{l}\mathbf{0 . 2 0} \\
4.96\end{array}$ & 0.12 \\
\hline \multicolumn{11}{|c|}{ Panel B: Unmanaged Earnings } \\
\hline UK & $\begin{array}{r}\mathbf{0 . 0 7} \\
17.43\end{array}$ & $\begin{array}{r}-\mathbf{0 . 0 1} \\
0.02\end{array}$ & $\begin{array}{l}\mathbf{0 . 0 2} \\
1.78\end{array}$ & $\begin{array}{r}\mathbf{0 . 2 1} \\
12.28\end{array}$ & 0.06 & $\begin{array}{l}\mathbf{0 . 0 7} \\
9.74\end{array}$ & $\begin{array}{r}\mathbf{0 . 0 0} \\
-1.61\end{array}$ & $\begin{array}{l}\mathbf{0 . 0 1} \\
0.39\end{array}$ & $\begin{array}{l}\mathbf{0 . 2 1} \\
6.50\end{array}$ & 0.07 \\
\hline France & $\begin{array}{l}\mathbf{0 . 0 5} \\
5.65\end{array}$ & $\begin{array}{l}-\mathbf{0 . 0 2} \\
-1.64\end{array}$ & $\begin{array}{l}\mathbf{0 . 0 3} \\
1.32\end{array}$ & $\begin{array}{l}\mathbf{0 . 0 5} \\
1.25\end{array}$ & 0.02 & $\begin{array}{l}\mathbf{0 . 0 4} \\
3.06\end{array}$ & $\begin{array}{l}\mathbf{0 . 0 0} \\
0.10\end{array}$ & $\begin{array}{l}\mathbf{0 . 0 5} \\
1.02\end{array}$ & $\begin{array}{l}\mathbf{0 . 1 5} \\
2.27\end{array}$ & 0.05 \\
\hline Germany & $\begin{array}{l}\mathbf{0 . 0 3} \\
3.25\end{array}$ & $\begin{array}{r}\mathbf{0 . 0 0} \\
-0.25\end{array}$ & $\begin{array}{r}\mathbf{0 . 0 1} \\
0.30\end{array}$ & $\begin{array}{l}\mathbf{0 . 0 8} \\
1.60\end{array}$ & 0.00 & $\begin{array}{l}\mathbf{0 . 0 4} \\
2.81\end{array}$ & $\begin{array}{r}\mathbf{0 . 0 0} \\
-0.47\end{array}$ & $\begin{array}{l}\mathbf{0 . 0 2} \\
0.69\end{array}$ & $\begin{array}{l}\mathbf{0 . 1 0} \\
2.58\end{array}$ & 0.02 \\
\hline
\end{tabular}


Notes:

Panel A: $\quad X_{t}=\beta_{0}+\beta_{1} D_{t}+\beta_{2} R_{t}+\beta_{3} R_{t} D_{t}+u_{t}$.

Panel B: $\quad X_{t}^{*}=\beta_{0}+\beta_{1} D_{t}+\beta_{2} R_{t}+\beta_{3} R_{t} D_{t}+u_{t}$

$R_{t}$ is the rate of return of the firm, that is $\left(P_{t}-P_{t-1}\right) / P_{t-1}$. Share prices have been adjusted for stock splits, new equity issues, etc. ., $D$ is a dummy variable that takes value 1 in case of bad news (negative or zero rate of return) and 0 in case of good news (positive rate of return).

$X_{t}$ is earnings before extraordinary items per share (DataStream item 254) deflated by share price at the beginning of the period.

$$
X^{*}{ }_{t}=\left(\mathrm{EPS}_{t}-\mathrm{DACCPS}_{t}\right) / P_{t-1}
$$

where EPS is earnings before extraordinary items per share (DS254), DACCPS is discretionary accruals per share. We define discretionary accruals (or abnormal accruals) as the prediction error of the total accruals version of the standard Jones (1991) model, multiplied by total book value of assets in period $t-1$.The standard Jones (1991) model as applied to total accruals is as follows: TACC/LTA $=\beta_{0}(1 / \mathrm{LTA})+\beta_{1} \Delta \mathrm{REV} /$ $\mathrm{LTA}+\beta_{2} \mathrm{PPE} / \mathrm{LTA}+\varepsilon$ Where TACC is total accruals [DataStream items $\left.\Delta(376-375)-\Delta(389-309)-(402+562)\right]$, REV is total sales $($ DS104), PPE is gross property, plant and equipment (DS330) and LTA is total assets (DS392) in period $t-1$.

We use the Fama and MacBeth (1973) methodology to cope with the possible cross-sectional dependence problems. The coefficients of the parameters have been obtained as the simple average from annual cross-section regressions. The $t$-statistics are the ratios of the mean estimated coefficients to the standard deviation of the distribution of the annual estimated slope coefficients, divided by the square root of the number of years.

$t$-statistics are White (1980) heteroskedasticity consistent 
in the coefficient of approximately $69 \%$ for France and $64 \%$ for Germany. The decrease in the $\beta_{3}$ coefficient is statistically significant at a $5 \%$ level in the cases of Germany and France, while it is not significant in the case of the UK. ${ }^{16}$ The coefficient on the intercepts remains approximately equal to the original Basu model estimates in all countries. It is also interesting to note that the good news coefficient $\left(\beta_{2}\right)$ becomes not significant after controlling for discretionary accruals. This is not consistent with a decrease in the association between earnings and returns in good news periods due to the usage of income decreasing earnings management. This result could be attributable to managers using positive discretionary accruals to align earnings and returns in good news periods (Guay et al., 1996), which could be partially offsetting the effect of the negative discretionary accruals used for the income decreasing strategies. However, good news captured in earnings through discretionary accruals is not significant, as we can see in Table 3.

We also use Fama and MacBeth (1973) mean annual regressions to discard the possibility of our results being influenced by cross-sectional dependence problems. The results using the mean annual regressions are very similar to the ones obtained with the pooled regressions. ${ }^{17}$

It is also interesting to point out the decrease in the $R^{2} \mathrm{~s}$ in all countries. This is not surprising, given that we are now using as the dependent variable a measure of the performance of the company closer to cash flows. As previous studies point out accruals are value relevant (Dechow, 1994; and Ball et al., 2000). When we remove from earnings one part of the accruals the reduction on the association is straightforward. Ball et al. (2000, p. 36) when measuring the association between cash flow from operations and returns obtain $R^{2}$ s of between 1 and 4 per cent, depending on the country. An alternative explanation (see Guay et al., 1996) is that firms manage earnings to improve

16 We estimate the statistical significance of the differences between coefficients in regressions using observed and unmanaged earnings as $\theta_{1}-\theta_{2}$ divided by $\sqrt{\sigma_{1}^{2}+\sigma_{2}^{2}}$ where $\theta_{i}$ is the estimated coefficient and $\sigma_{i}$ the standard error for variable $i$.

17 Fama and MacBeth (1973) regressions should be interpreted with caution. Basu (1999) gives a number of reasons against the use of mean annual regressions, related mainly to the parameters not being stationary. 
Table 3

Individual Regressions of Discretionary Accruals on Returns by Country

\begin{tabular}{lrcccc}
\hline & \multicolumn{5}{c}{ Pooled Regressions } \\
\cline { 2 - 6 } Discretionary Accruals & $\beta_{0}$ & $\beta_{1}$ & $\beta_{2}$ & $\beta_{3}$ & \\
\hline UK & $t$-stat & $t$-stat & $t$-stat & $t$-stat & Adj. $R^{2}$ \\
France & $-\mathbf{0 . 0 1}$ & $\mathbf{0 . 0 1}$ & $-\mathbf{0 . 0 0}$ & $\mathbf{0 . 0 4}$ & \multirow{2}{*}{0.001} \\
& -1.40 & 1.83 & -0.08 & 2.63 & \\
Germany & $\mathbf{0 . 0 0}$ & $\mathbf{0 . 0 2}$ & $-\mathbf{0 . 0 1}$ & $\mathbf{0 . 1 1}$ & \multirow{2}{*}{0.006} \\
& 0.37 & 1.52 & -0.28 & 3.02 & \\
& $-\mathbf{0 . 0 1}$ & $\mathbf{0 . 0 1}$ & $\mathbf{0 . 0 1}$ & $\mathbf{0 . 1 1}$ & 0.004 \\
\hline
\end{tabular}

Notes:

$$
\operatorname{DACCPS}_{t}=\beta_{0}+\beta_{1} D_{t}+\beta_{2} R_{t}+\beta_{3} R_{t} D_{t}+u_{t}
$$

$R_{t}$ is the rate of return of the firm, that is $\left(P_{t}-P_{t-1}\right) / P_{t-1}$. Share prices have been adjusted for stock splits, new equity issues, etc. .., $D$ is a dummy variable that takes value 1 in case of bad news (negative or zero rate of return) and 0 in case of good news (positive rate of return).

DACCPS $_{t}$ is discretionary accruals per share. We define discretionary accruals (or abnormal accruals) as the prediction error of the total accruals version of the standard Jones (1991) model, multiplied by total book value of assets in period $t-1$. The standard Jones (1991) model as applied to total accruals is as follows: TACC/LTA $=\beta_{0}(1 / \mathrm{LTA})+\beta_{1} \Delta \mathrm{REV} /$ LTA $+\beta_{2} \mathrm{PPE} / \mathrm{LTA}+\varepsilon$ Where TACC is total accruals [DataStream items $\Delta(376-375)-\Delta(389-309)-(402+562)]$, REV is total sales (DS104), PPE is gross property, plant and equipment (DS330) and LTA is total assets (DS392) in period $t-1$.

$t$-statistics are White (1980) heteroskedasticity consistent.

the relation between earnings and changes in value, and consequently, that discretionary accruals are relevant. Guay et al. (1996, p. 98) examine also the association between earnings (managed and unmanaged) and returns in the US and find that the $R^{2}$ decreases from 9 per cent to between 7 and 1 per cent, depending on the model used to estimate discretionary accruals. Our results are consistent with those in both Guay et al. (1996) and Ball et al. (2000).

As expected, and consistent with our results in Table 2, we find that discretionary accruals exhibit an asymmetric association with returns. In Table 3 we show the results of a regression of discretionary accruals on returns. The $\beta_{3}$ coefficient, which shows the differential recognition speed of bad news through discretionary accruals, is in all three countries significantly positive. However, the recognition of good news through discretionary accruals, captured by $\beta_{2}$, is not significant. 
Finally, we analyse whether the differences that arise between countries once we incorporate discretionary accruals are significant. To do that we run the previous regressions, but instead of running one regression per country, we use just one model for all countries, incorporating the differential effect of each country using dummy variables. We use the UK as a reference country given that it is a priori, and also consistent with results in Table 2 Panel $\mathrm{B}$, the most different of the three countries under study.

If we focus on Table 4, Panel A, we see that differences exist only between the UK and France when using observed ('managed') earnings. However, when we remove discretionary accruals from earnings, the differences between countries are much more noticeable (Table 4, Panel B). The incremental bad news coefficient in France (Germany) with respect to the UK is $-0.15(-0.13)$, significant at $5 \%$. With respect to good news, there are no differences in the coefficient between countries regardless of whether we use observed or unmanaged earnings.

The results of this pooled country model could be biased as we make the strong assumption that the variance of the disturbance term in all 3 countries is equal. To avoid this problem and compare the three countries without making this assumption we test the differences in the coefficients across countries in the same way as we test the significance of the decrease in the bad news coefficient from managed to unmanaged earnings (see footnote 16). This analysis confirms the results obtained with the pooled country and dummy variables regression.

To test whether our results are sensitive to the model used to calculate discretionary accruals we replicate the analysis using the following additional accruals models: the Jones (1991) working capital accruals model, the Modified Jones (Dechow et al. 1995) working capital accruals and total accruals models, and the margin model proposed by Peasnell et al. (2000a). Results are similar to those obtained with the Jones (1991) total accruals model, although the decreases in the $\beta_{3}$ (conservatism coefficient) are more pronounced when we use total accruals models.

Figure 3 compares the decrease in the earnings conservatism measure (percentage change in $\beta_{3}$ coefficient from using observed earnings to using unmanaged earnings) in all 3 countries and across all accruals models. It can be observed that the 
Table 4

Between Countries Comparative Analysis on Earnings Conservatism

\begin{tabular}{|c|c|c|c|c|c|}
\hline Panel A: Observed Earnings & $\begin{array}{c}\beta_{0} \\
t \text {-stat }\end{array}$ & $\begin{array}{c}\beta_{1} \\
t \text {-stat }\end{array}$ & $\begin{array}{c}\beta_{2} \\
t \text {-stat }\end{array}$ & $\begin{array}{c}\beta_{3} \\
t \text {-stat }\end{array}$ & $\operatorname{Adj} . R^{2}$ \\
\hline \multirow[t]{2}{*}{ UK } & $\begin{array}{r}\mathbf{0 . 0 7} \\
30.26\end{array}$ & $\begin{array}{l}\mathbf{0 . 0 1} \\
1.37\end{array}$ & $\begin{array}{l}\mathbf{0 . 0 2} \\
3.65\end{array}$ & $\begin{array}{r}\mathbf{0 . 2 4} \\
18.79\end{array}$ & 0.14 \\
\hline & $\begin{array}{c}\beta_{0 j} \\
t \text {-stat }\end{array}$ & $\begin{array}{c}\beta_{1 j} \\
t \text {-stat }\end{array}$ & $\begin{array}{c}\beta_{2 j} \\
t \text {-stat }\end{array}$ & $\begin{array}{c}\beta_{3 j} \\
t \text {-stat }\end{array}$ & \\
\hline France & $\begin{array}{l}-\mathbf{0 . 0 1} \\
-2.05\end{array}$ & $\begin{array}{l}-\mathbf{0 . 0 1} \\
-0.95\end{array}$ & $\begin{array}{l}-\mathbf{0 . 0 0} \\
-0.21\end{array}$ & $\begin{array}{l}-\mathbf{0 . 0 9} \\
-3.24\end{array}$ & \\
\hline Germany & $\begin{array}{l}-\mathbf{0 . 0 3} \\
-7.27\end{array}$ & $\begin{array}{c}\mathbf{0 . 0 0} \\
0.74\end{array}$ & $\begin{array}{l}-\mathbf{0 . 0 0} \\
-0.28\end{array}$ & $\begin{array}{l}-\mathbf{0 . 0 2} \\
-0.92\end{array}$ & \\
\hline
\end{tabular}


Table 4 (Continued)

\begin{tabular}{|c|c|c|c|c|c|}
\hline Panel B: Unmanaged Earnings & $\underset{\text { t-stat }}{\beta_{0}}$ & $\underset{\text { t-stat }}{\beta_{1}}$ & $\underset{\text { t-stat }}{\beta_{2}}$ & $\underset{\text { t-stat }}{\beta_{3}}$ & Adj. $R^{2}$ \\
\hline \multirow[t]{2}{*}{ UK } & $\begin{array}{r}0.07 \\
17.43\end{array}$ & $\begin{array}{r}-0.01 \\
0.02\end{array}$ & $\begin{array}{l}0.02 \\
1.78\end{array}$ & $\begin{array}{c}0.21 \\
12.28\end{array}$ & 0.04 \\
\hline & $\underset{t \text {-stat }}{\beta_{0 j}}$ & $\underset{t \text {-stat }}{\beta_{1 j}}$ & $\underset{t \text {-stat }}{\beta_{2 j}}$ & $\underset{t \text {-stat }}{\beta_{3 j}}$ & \\
\hline France & $\begin{array}{l}-\mathbf{0 . 0 2} \\
-1.96\end{array}$ & $\begin{array}{l}-\mathbf{0 . 0 2} \\
-1.20\end{array}$ & $\begin{array}{l}\mathbf{0 . 0 1} \\
0.37\end{array}$ & $\begin{array}{l}-0.15 \\
-3.43\end{array}$ & \\
\hline Germany & $\begin{array}{l}-\mathbf{0 . 0 4} \\
-3.62\end{array}$ & $\begin{array}{l}\mathbf{0 . 0 0} \\
O .11\end{array}$ & $\begin{array}{l}-\mathbf{0 . 0 1} \\
-0.32\end{array}$ & $\begin{array}{l}-\mathbf{0 . 1 3} \\
-2.57\end{array}$ & \\
\hline
\end{tabular}

Notes:

Panel A: $\quad X_{t}=\beta_{0}+\Sigma_{j} \beta_{0 j} C D_{j}+\beta_{1} R D_{t}+\Sigma_{j} \beta_{1 j} C D_{j} R D_{t}+\beta_{2} R_{t}+\Sigma_{j} \beta_{2 j} C D_{j} R_{t}+\beta_{3} R_{t} R D_{t}+\Sigma_{j} \beta_{3 j} R_{t} C D_{j} R D_{t}+u$

Panel B: $\quad X_{t}^{*}=\beta_{0}+\Sigma_{j} \beta_{0 j} C D_{j}+\beta_{1} R D_{t}+\Sigma_{j} \beta_{1 j} C D_{j} R D_{t}+\beta_{2} R_{t}+\Sigma_{j} \beta_{2 j} C D_{j} R_{t}+\beta_{3} R_{t} R D_{t}+\Sigma_{j} \beta_{3 j} R_{t} C D_{j} R D_{t}+u_{t}$

$R_{t}$ is the rate of return of the firm, that is $\left(P_{t}-P_{t-1}\right) / P_{t-1}$. Share prices have been adjusted for stock splits, new equity issues, etc. ., $D$ is a dummy variable that takes value 1 in case of bad news (negative or zero rate of return) and 0 in case of good news (positive rate of return). $C D$ is a country dummy that takes value 1 in the case of France and Germany, and value 0 otherwise. $X_{t}$ is earnings before extraordinary items per share (DataStream item 254) deflated by share price at the beginning of the period. $X^{*}{ }_{t}=\left(\mathrm{EPS}_{t}-\mathrm{DACCPS}_{t}\right) / P_{t-1}$ where EPS is earnings before extraordinary items per share (DS254) DACCPS is discretionary accruals per share. We define discretionary accruals (or abnormal accruals) as the prediction error of the total accruals version of the standard Jones (1991) model, multiplied by total book value of assets in period $t-1$. The standard Jones (1991) model as applied to total accruals is as follows: TACC/LTA $=\beta_{0}(1 / \mathrm{LTA})+\beta_{1} \Delta \mathrm{REV} / \mathrm{LTA}+\beta_{2}$ PPE$/ \mathrm{LTA}+\varepsilon$. Where TACC is total accruals [DataStream items $\Delta(376-375)-\Delta(389-309)-(402+562)]$, REV is total sales (DS104), PPE is gross property, plant and equipment (DS330) and LTA is total assets (DS392) in period $t-1$.

$t$-statistics are White (1980) heteroskedasticity consistent. 


\section{Figure 3}

Decrease in Differential Bad News Effect from Observed (Managed) to Unmanaged Earnings

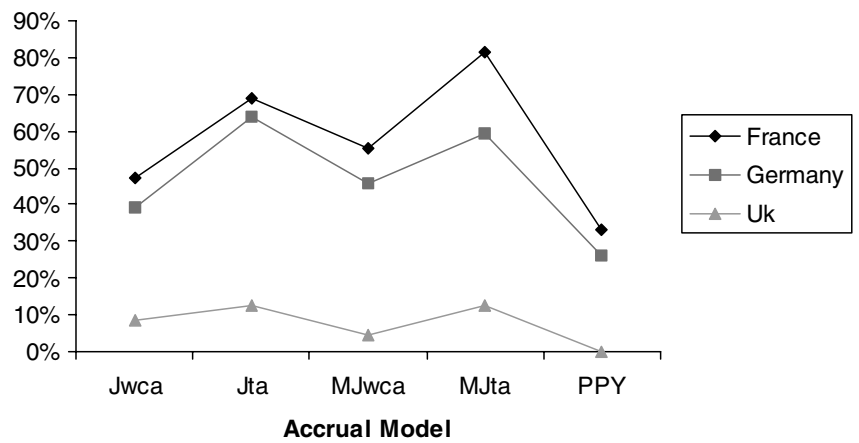

Notes:

Percentage change in $\beta_{3}$ from Panel A (with observed earnings) to Panel $\mathrm{B}$ (with unmanaged earnings), from Table 2, using the following models to calculate DACC:

Jwca: Jones (1991) model, working capital accruals.

Jta: Jones (1991) model, total accruals.

MJwca: Modified Jones (Dechow et al. 1995), working capital accruals.

MJta: Modified Jones (Dechow et al. 1995), total accruals.

PPY: Peasnell, Pope and Young (2000a). (Margin model.)

consistent decrease in the coefficient in France and Germany (which is significant at a $5 \%$ level in all models with the exception of the margin model proposed by Peasnell et al., 2000a), while in the UK, although the decrease exists, it is not so noticeable (it is only statistically significant at a $10 \%$ level when using the modified Jones total accruals model).

Pope and Walker (1999) analyse differences in earnings conservatism between the US and the UK. They show that when using earnings before extraordinary items, the US shows a much more pronounced conservatism bias than the UK. However, when they use bottom line earnings, that is, earnings after extraordinary items, they find that the level of earnings conservatism in both countries is very similar. This result suggests that when analysing earnings conservatism between countries, researchers should also consider the treatment given to extraordinary items. To avoid the distorting effect of a different 


\section{Figure 4}

Decrease in Differential Bad News Effect from Observed (Managed) to Unmanaged Earnings (Using Earnings After Extraordinary Items)

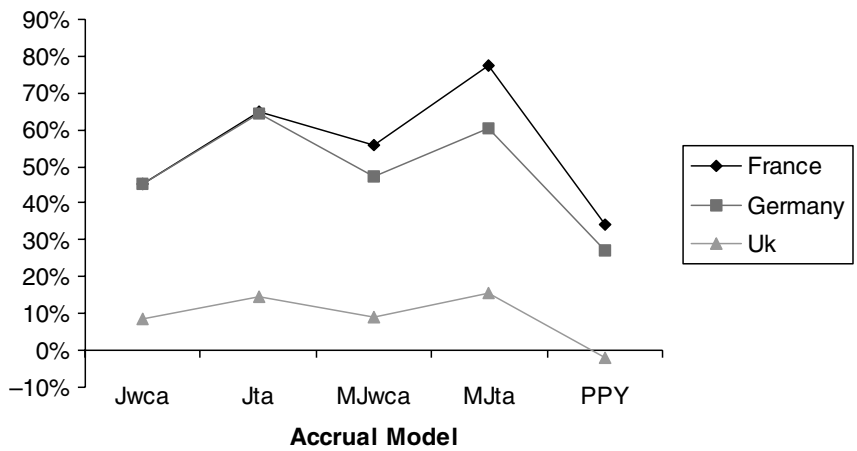

Notes:

Percentage change in $\beta_{3}$ from Panel A (with observed earnings) to Panel B (with unmanaged earnings), from regressions in Table 2, but using earnings after extraordinary items (DataStream item 254+[DataStream item 193/number of shares]). Number of shares is DS625/DS254. Using the following models to calculate the DACC: Jwca: Jones (1991) model, working capital accruals.

Jta: Jones (1991) model, total accruals.

MJwca: Modified Jones (Dechow et al. 1995), working capital accruals.

MJta: Modified Jones (Dechow et al. 1995), total accruals.

PPY: Peasnell, Pope and Young (2000a). (Margin model.)

classification of good and bad news within financial statements across countries (the possibility of news, especially bad news, being classified as extraordinary or exceptional items) we replicate all our analyses using earnings after extraordinary items. ${ }^{18}$ These results (see summary in Figure 4) are very similar to those obtained using earnings before extraordinary items.

Finally, and to control for within country factors (a different sample composition in each country, and whether this could affect the results), we split the sample into 3 sub-samples according to size (total assets) and another 3 according to growth (percentage change in sales: $\left.\left[\operatorname{sales}_{t}-\operatorname{sales}_{t-1}\right] / \operatorname{sales}_{t-1}\right)$. We find similar

18 We also control for the differences in the definitions of extraordinary/exceptional items introduced by FRS 3 in the United Kingdom. 
decreases in the conservatism coefficient after controlling for discretionary accruals in the three size sub-samples (see Table 5). In addition, we find that, consistent with prior literature, earnings conservatism for continental countries is more pronounced for small firms when using observed earnings. However, when we control for discretionary accruals these $a$ priori surprising results are not clear, and it appears that large firms are more conservative, as one should expect given that they should be more similar to common-law type firms. With respect to growth, results across the different growth sub-samples are consistent with our overall results. ${ }^{19}$

Our overall results indicate a decrease in the differential earnings response to bad news with respect to good news when using earnings minus discretionary accruals. This decrease is more pronounced in France and Germany than in the UK, and differences between the UK with respect to France and Germany in earnings conservatism become significant after controlling for discretionary accruals.

\section{SUMMARY AND CONCLUSIONS}

We show that in certain institutional contexts (weaker investor protection and less dispersed ownership structure), earnings management drives significantly the measures of earnings conservatism. Our results show that while earnings conservatism does not change significantly in the UK after removing the effect of discretionary accruals, in the cases of France and Germany the typical measure of earnings conservatism (the incremental bad news effect, in a regression of earnings on returns) suffers a significant reduction.

Our findings explain why in previous studies the measures of earnings conservatism in European continental countries were too large and too similar to those in the UK. We argue that managers in European continental countries have incentives to manage earnings downwards, and that this behaviour is likely to affect seriously the results of accounting research in Europe. The effects we document on earnings conservatism are just an

\footnotetext{
19 These results are not disclosed, but are available from the authors on request.
} 
Table 5

Earnings Conservatism by Country (Sensitivity Analysis by Size)

\begin{tabular}{|c|c|c|c|c|c|c|c|c|c|c|c|c|c|c|c|}
\hline & \multicolumn{5}{|c|}{ Small Firms } & \multicolumn{5}{|c|}{ Medium Firms } & \multicolumn{5}{|c|}{ Large Firms } \\
\hline & $\begin{array}{c}\beta_{O} \\
t \text {-stat }\end{array}$ & $\begin{array}{c}\beta_{1} \\
t \text {-stat }\end{array}$ & $\begin{array}{c}\beta_{2} \\
t \text {-stat }\end{array}$ & $\begin{array}{c}\beta_{3} \\
t \text {-stat }\end{array}$ & Adj. $R^{2}$ & $\begin{array}{c}\beta_{O} \\
t \text {-stat }\end{array}$ & $\begin{array}{c}\beta_{1} \\
t \text {-stat }\end{array}$ & $\underset{t-s t a t}{\beta_{2}}$ & $\begin{array}{c}\beta_{3} \\
t \text {-stat }\end{array}$ & Adj. $R^{2}$ & $\begin{array}{c}\beta_{O} \\
t \text {-stat }\end{array}$ & $\begin{array}{c}\beta_{1} \\
t-s t a t\end{array}$ & $\begin{array}{c}\beta_{2} \\
t \text {-stat }\end{array}$ & $\begin{array}{c}\beta_{3} \\
t \text {-stat }\end{array}$ & $\operatorname{Adj} . R^{2}$ \\
\hline \multicolumn{16}{|c|}{ Panel A: Observed Earnings } \\
\hline \multirow[t]{2}{*}{ UK } & 0.06 & -0.01 & 0.01 & 0.24 & & 0.07 & 0.01 & 0.03 & 0.22 & \multirow[b]{2}{*}{0.15} & 0.07 & 0.01 & 0.02 & 0.23 & \multirow[b]{2}{*}{0.15} \\
\hline & 10.64 & -1.21 & 1.38 & 10.67 & 0.13 & 19.14 & 2.22 & 4.45 & 10.69 & & 28.30 & 2.38 & 2.48 & 9.49 & \\
\hline \multirow{2}{*}{ France } & 0.05 & 0.01 & 0.03 & 0.16 & 017 & 0.06 & -0.01 & 0.01 & 0.15 & \multirow{2}{*}{0.10} & 0.06 & -0.02 & -0.00 & 0.14 & \multirow{2}{*}{0.08} \\
\hline & 7.17 & 0.94 & 2.75 & 4.46 & 0.17 & 10.56 & -0.79 & 0.49 & 3.54 & & 11.74 & -1.18 & -0.36 & 3.15 & \\
\hline \multirow[t]{2}{*}{ Germany } & 0.03 & 0.00 & 0.00 & 0.25 & \multirow{2}{*}{0.11} & 0.04 & 0.01 & 0.02 & 0.20 & \multirow{2}{*}{0.08} & 0.04 & 0.02 & 0.02 & 0.19 & \multirow{2}{*}{0.08} \\
\hline & 5.13 & 0.09 & 0.22 & 6.40 & & 4.37 & 0.80 & 0.89 & 4.94 & & 8.30 & 2.42 & 1.58 & 3.75 & \\
\hline \multicolumn{16}{|c|}{ Panel B: Unmanaged Earnings } \\
\hline \multirow[t]{2}{*}{ UK } & 0.06 & -0.02 & 0.02 & 0.18 & & 0.07 & -0.00 & 0.02 & 0.19 & \multirow[b]{2}{*}{0.05} & 0.08 & 0.01 & 0.03 & 0.22 & \multirow[b]{2}{*}{0.06} \\
\hline & 6.95 & -1.91 & 1.03 & 6.62 & 0.06 & 9.52 & -0.40 & 0.99 & 6.58 & & 14.22 & 1.51 & 1.97 & 6.39 & \\
\hline \multirow[t]{2}{*}{ France } & 0.04 & -0.01 & 0.07 & 0.02 & 006 & 0.07 & -0.02 & 0.04 & 0.05 & \multirow{2}{*}{0.02} & 0.06 & -0.05 & -0.06 & 0.12 & \multirow{2}{*}{0.01} \\
\hline & 2.88 & -0.25 & 3.17 & 0.32 & 0.00 & 3.60 & -0.82 & 0.89 & 0.50 & & 3.67 & -1.93 & -1.91 & 1.57 & \\
\hline \multirow[t]{2}{*}{ Germany } & 0.01 & 0.02 & 0.01 & 0.06 & \multirow{2}{*}{-0.00} & 0.04 & $-\mathbf{0 . 0 3}$ & -0.02 & 0.08 & \multirow{2}{*}{0.00} & 0.04 & 0.00 & 0.03 & 0.13 & \multirow{2}{*}{0.01} \\
\hline & 0.75 & 0.88 & 0.31 & 0.80 & & 2.29 & -0.96 & -0.42 & 0.84 & & 2.37 & 0.11 & 0.71 & 1.43 & \\
\hline
\end{tabular}


Notes:

Panel A: $\quad X_{t}=\beta_{0}+\beta_{1} D_{t}+\beta_{2} R_{t}+\beta_{3} R_{t} D_{t}+u_{t}$

Panel B: $\quad X_{t}^{*}=\beta_{0}+\beta_{1} D_{t}+\beta_{2} R_{t}+\beta_{3} R_{t} D_{t}+u_{t}$

$\boldsymbol{R}_{\boldsymbol{t}}$ is the rate of return of the firm, that is $\left(P_{t}-P_{t-1}\right) / P_{t-1}$. Share prices have been adjusted for stock splits, new equity issues, etc .., $D$ is a dummy variable that takes value 1 in case of bad news (negative or zero rate of return) and 0 in case of good news (positive rate of return).

$\boldsymbol{X}_{\boldsymbol{t}}$ is earnings before extraordinary items per share (DataStream item 254) deflated by share price at the beginning of the period.

$$
X_{t}^{*}=\left(\mathrm{EPS}_{t}-\mathrm{DACCPS}_{t}\right) / P_{t-1}
$$

where EPS is earnings before extraordinary items per share (DS254) DACCPS is discretionary accruals per share. We define discretionary accruals (or abnormal accruals) as the prediction error of the total accruals version of the standard Jones (1991) model, multiplied by total book value of assets in period $t-1$. The standard Jones (1991) model as applied to total accruals is as follows: TACC/LTA $=\beta_{0}(1 / \mathrm{LTA})+\beta_{1} \Delta \mathrm{REV} / \mathrm{LTA}+\beta_{2} \mathrm{PPE} / \mathrm{LTA}+\varepsilon$ Where TACC is total accruals [DataStream items $\Delta(376-375)-\Delta(389-309)-(402+562)]$, REV is total sales (DS104), PPE is gross property, plant and equipment (DS330) and LTA is total assets (DS392) in period $t-1$.

$t$-statistics are White (1980) heteroskedasticity consistent.

Number of observations per size group: Small: UK (3,377), France (455); Germany $(1,081)$

Medium and Large: UK (3,377), France (456), Germany $(1,082)$ 
example (the understatement of earnings could be affecting valuation models using earnings numbers, valuation using multiples, the earnings response coefficient in association models, etc...), and further investigation in this area should be pursued, especially at a time when the European Commission has set up comparability in accounting information as one of the main objectives regulators should seek in Europe. These differences also raise questions as to whether standardisation is enough to achieve comparability without harmonisation of incentives.

\section{REFERENCES}

Ball, R., S.P. Kothari and A. Robin (2000), 'The Effect of International Institutional Factors on Properties of Accounting Earnings', Journal of Accounting and Economics, Vol. 29 (February), pp. 1-51.

Basu, S. (1997), 'The Conservatism Principle and the Asymmetric Timeliness of Earnings', Journal of Accounting and Economics, Vol. 24 (December), pp. $3-37$.

(1999), 'Discussion of International Differences in the Timeliness, Conservatism and Classification of Earnings', Journal of Accounting Research, Vol. 37 (Supplement), pp. 89-99.

Beaver, W.H., M.F. McNichols and K.K. Nelson (2003), 'An Alternative Interpretation of the Discontinuity in Earnings Distributions', Working Paper (Stanford University).

Beneish, M.D. (1998), 'Discussion of 'Are Accruals During Initial Public Offering Opportunistic?”, Review of Accounting Studies, Vol. 3, No. 1, pp. 209-21.

DeAngelo, H. and L. DeAngelo (1991), 'Union Negotiations and Corporate Policy: A Study of Labor Concessions in the Domestic Steel Industry During the 1980s', Journal of Financial Economics, Vol. 30 (November), pp. 3-43.

Dechow, P.M. (1994), 'Accounting Earnings and Cash Flows as Measures of Firm Performance: The Role of Accounting Accruals', Journal of Accounting and Economics, Vol. 18 (July), pp. 3-42.

S.A. Richardson and I. Tuna (2003), 'Why are Earnings Kinky? An Examination of the Earnings Management Explanation', Review of Accounting Studies, Vol. 8 (June/September), pp. 355-84.

- 1 and D.J. Skinner (2000), 'Earnings Management: Reconciling the Views of Accounting Academics, Practitioners and Regulators', Accounting Horizons, Vol. 14 (June), pp. 235-50.

- R.G. Sloan and A.P. Sweeney (1995), 'Detecting Earnings Management', The Accounting Review, Vol. 70 (April), pp. 193-225.

Easton, P.D., T.S Harris and J.A. Ohlson (1992), 'Aggregate Accounting Earnings Can Explain Most of Security Returns', Journal of Accounting and Economics, Vol. 15 (June/September), pp. 119-42. 
Ehrhardt, O. and M. Schmidt (2003), 'Managerial Discretion in Internal Finance: A Test of Pecking Order and Accruals Management Under German Corporate and Accounting Regulation', Working Paper (Humboldt-University Berlin).

Fama, E. and K. French (2002), 'Testing Tradeoff and Pecking Order Predictions About Dividends and Debt', Review of Financial Studies, Vol. 15 (Spring), pp. 1-33.

— and J. MacBeth (1973), 'Risk, Return, and Equilibrium: Empirical Tests', Journal of Political Economy, Vol. 81 (May/June), pp. 607-36.

Feltham, G. and J.A. Ohlson (1995), 'Valuation and Clean Surplus Accounting for Operating and Financial Activities', Contemporary Accounting Research, Vol. 11 (Spring), pp. 689-732.

Financial Accounting Standards Board (1980), Statement of Financial Accounting Concepts No. 2, Qualitative Characteristics of Accounting Information (Norwalk, Connecticut).

Friedlan, J.M. (1994), 'Accounting Choices of Issuers of Initial Public Offerings', Contemporary Accounting Research, Vol. 11 (Summer), pp. 1-34.

García Lara, J.M. and A. Mora (2004), 'Balance Sheet versus Earnings Conservatism in Europe', The European Accounting Review, Vol. 13, pp. 261-92.

Gill de Albornoz Noguer, B. and M. Illueca Muñoz (2004), 'Comparing Abnormal Accruals Models: A Non-parametric Approach', Applied Economics, Vol. 36, No. 13, pp. 1455-60.

Giner, B. and W. Rees (2001), 'On the Asymmetric Recognition of Good and Bad News in France, Germany and the United Kingdom', Journal of Business, Finance $\varepsilon^{3}$ Accounting, Vol. 28 (November/December), pp. 1285-331.

Givoly, D. and C. Hayn (2000), 'The Changing Time-series Properties of Earnings, Cash Flows and Accruals: Has Financial Reporting Become More Conservative?', Journal of Accounting and Economics, Vol. 29 (June), pp. 287-320.

Gore, P., P.F. Pope and A.K. Singh (2002), 'Earnings Management and the Distribution of Earnings Relative to Targets: U.K. Evidence', Working Paper (Lancaster University).

Guay, W.R., S.P. Kothari and R.L. Watts (1996), 'A Market Based Evaluation of Discretionary Accruals Models', Journal of Accounting Research, Vol. 34 (Supplement), pp. 83-105.

Harris, T.S., M. Lang and P. Möller (1994), 'The Value Relevance of German Accounting Measures: An Empirical Analysis', Journal of Accounting Research, Vol. 32 (Autumn), pp. 187-209.

Healy, P.M. and J.M. Wahlen (1999), 'A Review of the Earnings Management Literature and its Implications for Standard Setters', Accounting Horizons, Vol. 13 (December), pp. 365-83.

International Accounting Standards Committee (1989), Framework for the Preparation and Presentation of Financial Statements (London).

Jensen, M. and W. Meckling (1976), 'Theory of the Firm: Managerial Behaviour, Agency Costs and Ownership Structure', Journal of Financial Economics, Vol. 3 (October), pp. 305-60.

Jones, J.J. (1991), 'Earnings Management During Import Relief Investigations', Journal of Accounting Research, Vol. 29 (Autumn), pp. 193-228.

Joos, P. (1997), 'The Stock Market Valuation of Earnings and Book Value Across International Accounting Systems,' Doctoral Thesis (UMI). - and M. Lang (1994), 'The Effects of Accounting Diversity: Evidence from the European Union', Journal of Accounting Research, Vol. 32 (Supplement), pp. 141-\68. 
Kasanen, E., J. Kinnunen and J. Niskanen (1996), 'Dividend-based Earnings Management: Empirical Evidence from Finland', Journal of Accounting and Economics, Vol. 22 (August-December), pp. 283-312.

La Porta, R., F. López-de-Silanes, A. Shleifer and R.W. Vishny (2000), 'Agency Problems and Dividend Policies Around the World', The Journal of Finance, Vol. 55 (February), pp. 1-33.

Lamb, M., C.W. Nobes and A. Roberts (1998), 'International Variations in the Connections Between Tax and Financial Reporting', Accounting and Business Research, Vol. 28 (Summer), pp. 173-88.

Leuz, C., D. Nanda and P.D. Wysocki (2003), 'Earnings Management and Investor Protection: An International Comparison', Journal of Financial Economics, Vol. 69 (September), pp. 505-27.

Liberty, S.E. and J.L. Zimmerman (1986), 'Labor Union Contract Negotiations and Accounting Choices', The Accounting Review, Vol. 61 (October), pp. 692-712.

Myers, S.C. (1984), 'The Capital Structure Puzzle', The Journal of Finance, Vol. 39 (July), pp. 575-92.

$\longrightarrow$ and N. Majluf (1984), 'Corporate Financing and Investment Decisions When Firms Have Information Investors Do Not Have', Journal of Financial Economics, Vol. 13 (June), pp. 187-221.

Peasnell, K.V., P.F. Pope and S. Young (2000a), 'Detecting Earnings Management Using Cross-sectional Abnormal Accruals Models', Accounting and Business Research, Vol. 30 (Autumn), pp. 313-26.

(2000b), 'Accrual Management to Meet Earnings Targets: UK Evidence Pre- and Post- Cadbury', British Accounting Review, Vol. 32 (December), pp. 415-45.

Pope, P.F. and M. Walker (1999), 'International Differences in the Timeliness, Conservatism and Classification of Earnings', Journal of Accounting Research, Vol. 37 (Supplement), pp. 53-87.

(2003), 'Ex-ante and Ex-post Accounting Conservatism, Asset Recognition and Asymmetric Earnings Timeliness', Working Paper (Lancaster University and University of Manchester).

Rangan, S. (1998), 'Earnings Management and the Performance of Seasoned Equity Offerings', Journal of Financial Economics, Vol. 50 (October), pp. 101-22.

Raonic, I., S.J. Mcleay and I. Asimakopoulos (2004), 'The Timeliness of Income Recognition by European Companies: An Analysis of Institutional and Market Complexity', Journal of Business Finance Eं Accounting, Vol. 31 (January), pp. 115-48.

Richard, J. (2001), 'France. Group Accounts', in D. Ordelheide (ed.), Transnational Accounting (2nd ed., Palgrave Publishers).

Seckler, G. (1998), 'Germany', in A. Alexander and S. Archer (eds.), European Accounting Guide (3rd ed., Harcourt Brace).

Teoh, S.H., I. Welch and T.J. Wong (1998), 'Earnings Management and the Underperformance of Seasoned Equity Offerings', Journal of Financial Economics, Vol. 50 (October), pp. 63-99.

White, H. (1980), 'A Heteroskedasticity-consistent Covariance Matrix Estimator and a Direct Test for Heteroskedasticity', Econometrica, Vol. 48 (May), pp. 817-38.

Young, S. (1999), 'Systematic Measurement Error in the Estimation of Discretionary Accruals: An Evaluation of Alternative Modelling Procedures', Journal of Business Finance E' Accounting, Vol. 26 (September/October), pp. 833-62. 